\title{
Rapid Testing of Salinity Effects on Pistachio Seedling Rootstock
}

\author{
G.A. Picchioni' and S. Miyamoto ${ }^{2}$ \\ Texes A\&M University Agricultural Research and Extension Center, 1380 A\&M Circle, El Paso, \\ TX 79927
}

\author{
J.B. Storey $^{3}$ \\ Department of Horticultural Sciences, Texas A\&M University, College Station, TX 77843-2133 \\ Additional index words. sodium chloride, sodium : calcium ratio, excised roots, Pistacia spp., screening methods, saline \\ tolerance, sodium exclusion, membrane permeability
}

\begin{abstract}
A laboratory procedure was used to evaluate saline tolerance of pistachio rootstock species. Results were compared to those from a 2-year, outdoor lysimeter study to test reliability of the method. Excised root tips from seedlings of Pistacia atlantica Desf., $P$. terebinthus L. (two selections), and $P$. integerrima Stewart $\times$ atlantica (Pioneer Gold II, or PG II), were exposed to laboratory solutions that simulated soil solution electrical conductivity (EC) and $\mathrm{Na}$ : Ca ratios in the lysimeters. Following 24 hours of incubation, the efflux of ultraviolet (UV)-absorbing solutes was measured, providing an indication of cell membrane permeability. Leakage occurred with saline solutions comparable to lysimeter soil water salinity that increased leaf Na concentrations and decreased average root growth (175 mM NaCl with $\left.12.5 \mathrm{~mm} \mathrm{Ca,} \mathrm{or} \mathrm{EC} \mathrm{of} 18.1 \mathrm{dS}^{\prime} \mathrm{m}^{-1}\right)$. Cell injury increased linearly with salinity $\left(R^{2}=0.81\right)$ and was highest in root tips of a $P$. terebinthus selection having least Na exclusion capability in the lysimeters. On average, these excised roots lost $38 \%$ more solutes than roots of a stronger Na-excluding genotype. There were no differences in leakage responses of the other species and selections. Leakage intensity was independent of various stress media, including isosmotic $\mathrm{CaCl}_{2}$, mannitol, and the simulated $\mathrm{Na} / \mathrm{Ca}$ mixtures in molar ratios of 10:1 to 20:1. With no Ca, however, damage caused by isosmotic $\mathrm{NaCl}$ was $76 \%$ to $87 \%$ higher, indicating that for these species, the $\mathrm{Na}$ : $\mathrm{Ca}$ ratio can alter root cell membrane permeability. Correlation between long-term observations in the lysimeters and leakage occurrence in the laboratory indicates that solute leakage tests with roots may aid in characterizing Pistacia spp. rootstocks for saline condition.
\end{abstract}

Empirical screening of rootstock for saline resistance can involve lengthy and extensive evaluations, but a simpler method could aid in the characterization process. The reliability of a rapid procedure could be determined by comparing results to responses obtained in a more natural environment, such as outdoor lysimeters. For example, Greenway (1970) proposed that short-term studies of excised roots, which reveal immediate consequences of salinity, may provide useful comparisons to longterm responses measured in natural conditions. Based on results with various crop species,. Nassery (1979) suggested that measurement of $\mathrm{K}$ loss from excised root segments may accurately and rapidly estimate salt resistance of plants. Milbocker (1988) achieved a close correlation between the induction of cell plasmolysis in root tips and a conventional, long-term screening procedure for the ranking of salt resistance of seven azalea cultivars.

Passive release of UV-absorbing solutes from plant tissues also measures short-term salinity effects. Rauser and Hanson (1966) showed $\mathrm{Na}$ and $\mathrm{K}$ salts (50 mm concentrations and above) induced leakage of UV-absorbing materials from excised root tips of soybean. Several workers have applied this criterion to the study of salt-affected leaf disks (Leopold and Willing, 1984; Redmann et al., 1986). Leakage of UV-absorbing solutes upon

Received for publication 13 Mar. 1990. Contribution from the Texas Agricultural Experiment Station and supported in part by the Expanded Research Area Fund of the Experiment Station. Appreciation is extended to the Entek Corp. (Grapevine, Texas) for donation of "Micro II" tubing used for solution cultures. The cost of publishing this paper was defrayed in part by the payment of page charges. Under postal regulations, this paper therefore must be hereby marked advertisement solely to indicate this fact.

'Graduate research assistant and Thomas B. Slick Fellow. Present address: Dept. of Pomology, Univ. of California, Davis, CA 95616.

${ }^{2}$ Professor of Soil and Water Sciences.

${ }^{3}$ Professor of Horticultural Sciences. injury is interpreted as direct injury to cell membranes (Leopold and Willing, 1984; Willing and Leopold, 1983).

We could find no reports incorporating long-term observations of growth and ion uptake of salt-treated rootstock with short-term laboratory responses using the UV-absorbing solute technique. Cell membranes of roots must endure immediate effects of salinity due to direct exposure to the soil solution (Maas and Nieman, 1978), a condition that could be simulated in the laboratory and observed by UV-absorption measurement.

The objectives of this study were to 1) assess salinity responses of root tips from two pistachio rootstock species and one hybrid using the UV-absorbing solute technique, and 2) compare these results to those obtained from a previous, longterm study involving the same rootstock.

\section{Materials and Methods}

Seedling culture and test material. Seedlings of $P$. atlantica (PI 246336), P. terebinthus (PI 246341 and 246342, referred to as $\mathrm{A}$ and $\mathrm{B}$, respectively), and $P$. integerrima $\times$ atlantica $(\mathrm{PG}$ II) were maintained in an open shadehouse for 3 years in 10liter plastic pots containing Hueco sandy loam soil (calcareous, coarse silty, mixed, thermic, Petrocalcic Paleargid). The seedlings were from the same experimental population of a previous salinity study made in outdoor lysimeters (Picchioni et al., 1990) but had not been used previously. On 22 Mar. 1989, dormant plants were moved to a greenhouse and tops were pruned back by $\approx 25 \%$ (to 0.3 to $0.6 \mathrm{~m}$ high). Roots were washed free of soil, and individual seedlings were transplanted into sealed, 16liter plastic pots containing complete, full-strength Hoagland nutrient solution \#1 (Hoagland and Arnon, 1950). Aeration was provided continuously by "Micro II" tubing (Entek Corp., Grapevine, Texas), glued to the base of each pot, and connected to a pressure pump providing a flow rate of $3.2 \times 10^{-4} \mathrm{~m}^{3} / \mathrm{sec}$ per pot. The greenhouse was maintained between a minimum 
of $21 \mathrm{C}$ at night and maximum of $27 \mathrm{C}$ during the day. Throughout the 7-week study, nutrient solution $\mathrm{pH}$ varied between 5.5 and 6.5, and was renewed and adjusted to $\mathrm{pH} 5.5$ (with $1 \mathrm{~N}$ $\mathrm{NaOH}$ or $\mathrm{HC} 1$ ) every 14 days. Midway between changes, solution was added to replace transpirational losses (ranging from 150 to $300 \mathrm{ml} \cdot \mathrm{day}^{-1}$ ) and maintain upper structural roots below the surface of the solution.

Within 4 weeks, seedlings had vigorous tops with fully expanded leaves, three to five elongating shoots, and new roots. Such roots are described for other woody species as having rapid extension growth and subsequent secondary thickening; e.g., white "extension" roots of grapevine (Richards, 1983), and white "axial" roots of various rootstock (Rem, 1987). They are likely an important zone for water and nutrient absorption. In our study, visible laterals ( $\geq 5 \mathrm{~cm}$ proximal to the tip) were formed no sooner than 3 to 4 weeks after appearance of the primary structures. In soil environments, new roots of $P$. integerrima have similar characteristics (e.g., white tips with rapid elongation) when observed through rhizotrons (Goldhammer et al., 1989; D. Goldhammer, personal communication). With the exception of diameter $(0.5$ to $1.5 \mathrm{~mm})$, selected roots were morphologically similar.

Testing procedure. Four solute leakage trials (1 to 4) were made between 21 Apr. and 6 June 1989. All laboratory procedures were developed in preliminary experiments (Picchioni, 1989). One root per plant per treatment was removed in the greenhouse, then shortened to $2 \mathrm{~cm}$ from the tip using a razor blade. Preliminary observation indicated that the distal 1 to 2 $\mathrm{cm}$ was the most salt-sensitive zone of new roots. Root tips were taken to a laboratory in $5 \mathrm{ml}$ of $0.5 \mathrm{mM} \mathrm{CaCl}_{2}$, shaken for $24 \mathrm{~h}$, and transferred to saline solutions for an additional 24 h. To accelerate leakage rates (Leopold and Willing, 1984), roots were next place in distilled water for $4 \mathrm{~h}$. This released $\approx 85 \%$ of the solutes resulting from saline injury.

Absorbance at $260 \mathrm{~nm}\left(\mathrm{~A}_{260}\right)$ of the 4- incubation solutions (3-ml samples) was measured using a Spectronic 21 UVD Spectrophotometer (Bausch and Lomb Instruments, Inc., Rochester, N.Y.). Solutions were returned to their original containers, sealed, and frozen at $-25 \mathrm{C}$ for $24 \mathrm{~h}$. Preliminary results showed this temperature, which was the most practical during the experimental period, provided $96 \% \pm 1 \%$ of solutes released by $-55 \mathrm{C}$. The $\mathrm{A}_{260}$ was again recorded after thawing and 4-h incubation, which liberated $\approx 75 \%$ of the total possible solutes. The sampling of incubation solutions (before and after freezing) was made at $4 \mathrm{~h} \pm 5 \mathrm{sec}$. Solutions were centrifuged at $1260 \times \mathrm{g}$ before $\mathrm{A}_{260}$ measurements. All incubations (5-ml volumes) were made in 125-ml flasks (slightly angled) at $\mathrm{pH} 6.1 \mathrm{using}$ a reciprocal shaker $(240 \mathrm{rpm})$ at the lowest setting. The laboratory was at $23.5 \pm 0.5 \mathrm{C}$, with lighting (cool-white fluorescent) providing $<10 \mu \mathrm{mol} \cdot \mathrm{s}^{-1} \cdot \mathrm{m}^{-2}$.

Relative leakage ratio (RLR) was calculated as the fraction of $A_{260}$ after salt treatment, but before freezing, to that after freezing. The background leakage from control roots, incubated in distilled water, was corrected to calculate an index of treatment injury $\left(\mathrm{I}_{\mathrm{t}}\right)$ :

$$
\mathrm{I}_{\mathrm{t}}(\%)=\left(\mathrm{RLR}_{\mathrm{t}}-\mathrm{RLR}_{\mathrm{c}}\right) /\left(1-\mathrm{RLR}_{\mathrm{c}}\right) \times 100,
$$

where $R_{L} R_{t}$ and $R L R_{c}$ refer to salt and control treatment samples, respectively. This equation uses the RLR of each treated replicate and the RLR of the control treatment mean (Flint et al., 1967).

Species comparison (trial 1). Six salt concentrations that approximated $\mathrm{EC}$ and $\mathrm{Na}$ : $\mathrm{Ca}$ molar ratios at the mean soil water content in the lysimeter soils (Picchioni et al., 1990) were applied to $P$. atlantica, $P$. terebinthus A, and PG II roots. The EC values for the control, 125:12.5, 175:17.5, and 250:25.0 $(\mathrm{mm} \mathrm{Na}: \mathrm{Ca})$ treatment solutions were $2.3 \times 10^{-3}, 14 .^{7} 18.7$. and $24.9 \mathrm{dS} \cdot \mathrm{m}^{-1}$, respectively. To more closely simulate lysimeter soils, which had a $\mathrm{CaSO}_{4}$ volubility limit in solution (Picchioni et al., 1990), Ca concentrations were held constant in two additional solutions at the highest $\mathrm{Na}$ concentrations, providing increased $\mathrm{Na}$ : Ca ratios (14:1 and 20:1). Salinity of the additional $175: 12.5$ and $250: 12.5$ solutions was 17.4 and 22.3 $\mathrm{dS} \cdot \mathrm{m}^{-1}$, respectively.

Responses of $\mathrm{P}$. terebinthus genotypes (trial 2). The leakage from roots of $P$. terebinthus A and B selections was compared in duplicate trials, and the results were combined. P. terebinthus $B$ seedlings have been shown to maintain the lowest root and basal stem but highest leaf $\mathrm{Na}$ concentrations at high salinity compared to other rootstock selections (Picchioni et al., 1990). Only the control, 175:12.5, and 250:12.5 treatments or those of equivalent osmolality were applied in this and in subsequent trials. The EC values were $2.5 \times 10^{-2}, 17.6$, and $23.2 \mathrm{dS} \cdot \mathrm{m}^{-1}$, respectively.

Isosmotic solutions (trials 3 and 4). To evaluate solute specificity, $\mathrm{Na} / \mathrm{Ca}, \mathrm{CaCl}_{2}$, mannitol, and $\mathrm{NaCl}$ without $\mathrm{Ca}(\mathrm{Na} / 0$ Ca) were applied to PG II (trial 3) and P. atlantica (trial 4). The treatments were isosmotic to the $175: 12.5$ and $250: 12.5$ $\mathrm{Na} / \mathrm{Ca}$ solutions (359 and $497 \mathrm{mOsm} \cdot \mathrm{kg}^{-1}$ respectively). Osmolality, measured with a cryoscopic osmometer (Osmette S, Precision Instruments, Sudbury, Mass.), varied by $<0.3 \%$ among the isosmotic solutions.

Statistical analyses. Twelve seedlings (three per species or selection) were maintained in a randomized complete block in the greenhouse. For laboratory incubations, three blocks were arranged in split plots. The main plots (salinity level in trials 1 and 2, osmolality in trials 3 and 4), were randomized completely within each block. Each seedling provided one root per incubation solution and was assigned to a specific incubation block. Subplots were rootstock species or selection (trials 1 and 2) and solute type (trials 3 and 4). Incubation and solution sampling began with the first block and ended with the third. Analyses of variance were made for the split-plot according to Little and Hills (1978). For linear effects of salinity (orthogonal contrast in trial 1), rootstock responses were evaluated by slope and intercept comparisons (Snedecor and Cochran, 1989). Main plot and subplot effects were verified by $\mathrm{F}$ test, and subplots were distinguished by least significant difference (LSD), calculated using the formulas of Little and Hills for a split plot (1978). Multiple subplot comparisons were made using Duncan's multiple range test. For interactions in trials 3 and 4, orthogonal contrasts were made between $\mathrm{Na} / \mathrm{O} \mathrm{Ca}$ and the remaining solutions.

\section{Results}

Rootstock species. The $\mathrm{I}_{\mathrm{t}}$ values in Eq. [1] represent leakage from root tips resulting only from saline treatment, even though control roots lost appreciable amounts of UV-absorbing solutes. In trial 1, however, RLR did not increase until $\mathrm{NaCl}$ was raised to $175 \mathrm{~mm}$ (Fig. 1). Within 175- and $250-\mathrm{mM} \mathrm{NaCl}$ levels, $\mathrm{Ca}$ application rate ( $\mathrm{Na}$ : $\mathrm{Ca}$ ratios of $10: 1$ to $20: 1$ ) did not alter root injury. For all rootstocks combined, $\mathrm{I}_{\mathrm{t}}$ averages were $31.5 \%$ vs. $32.3 \%$ for $175: 17.5(10: 1)$ and $175: 12.5(14: 1)$, and $72.3 \%$ vs. $68.7 \%$ for $250: 25.0(10: 1)$ and $250: 12.5(20: 1)$ solutions, respectively $(\mathrm{LSD}=14.6 \%)$. Data from both $\mathrm{Ca}$ treatments were then combined for further analyses. 


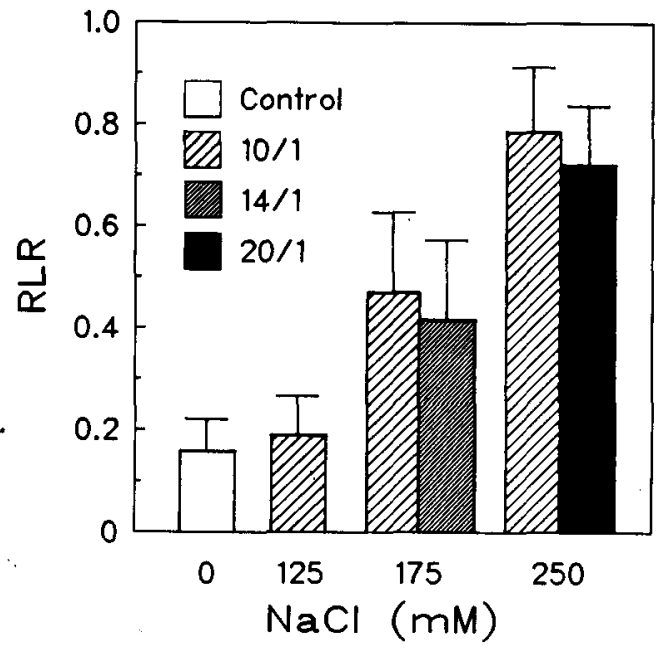

Fig. 1. Comparison of relative leakage ratio (RLR) in control (0 $\mathrm{NaCl}$ ) and saline media with $\mathrm{Na}$ : Ca molar ratios of 10):1, 14:1, and 20:1 (trial 1). Data represent the main plot averages for each treatment solution, for P. atlantica, P. terebinthus A, and PG II combined. Bars are the standard deviation of the mean of nine observations (LSD $=0.11, P=0.05)$. Subplots (rootstock species) were the average of three replicates each.

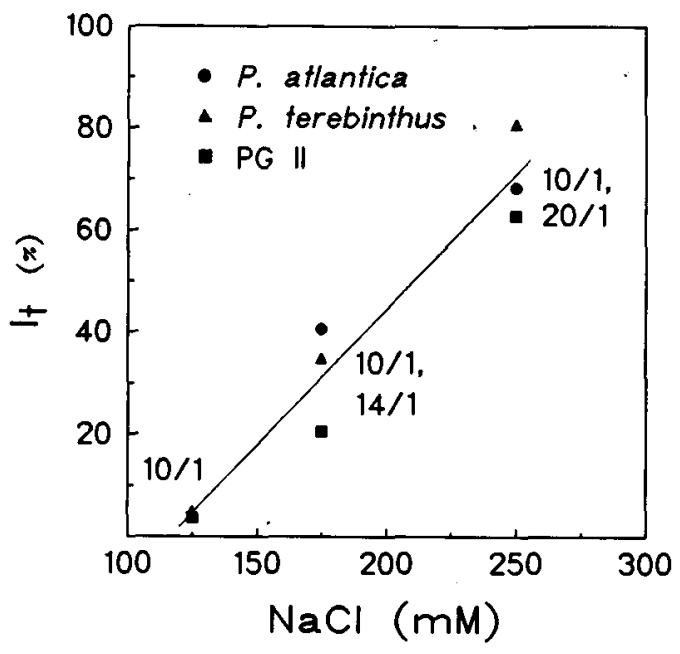

Fig. 2. Leakage from root tips ( $\mathrm{I}$ of rootstock in trial 1 ( $\mathrm{I}$ calculated as in Table 1). The $\mathrm{Na}$ : $\mathrm{Ca}$ ratios are next to points representing the mean of three replicates, with data from both $\mathrm{Na}: \mathrm{Ca}$ ratios averaged at 175 and $250 \mathrm{~mm} \mathrm{NaC1}$. Combined regression for line shown: $\mathrm{I}_{\mathrm{t}}=4.6+0.53(\mathrm{mM} \mathrm{NaCl}-125), R^{2}=0.81, \mathrm{n}=27$.

Salinity effects resulted from the linear increase in $\mathrm{I}_{t}$ with salt concentration (the linear contrast accounted for $100 \%$ of the salinity variation). On average, $175 \mathrm{mmNaCl}$ raised It by $\approx 8$ times, with high salinity $(250 \mathrm{~mm})$ resulting in a further doubling (Fig. 2). There were no I differences between rootstock species (nonsignificance for $\mathrm{F}$ test and regression comparisons); thus, all data were combined for an overall regression. Within this range of salinity and $\mathrm{Na}$ : Ca ratios, $\mathrm{I}_{\mathrm{t}}$ increased 5.370 with each 10-mm increase in $\mathrm{NaCl}$ concentration.

P. terebinthus genotypes. Large increases in leakage occurred with $P$. terebinthus A and B roots exposed to high salinity (Table 1 ), the magnitude (average of $\approx 2.8$ times) being similar to that of the same treatment interval of trial 1.P. terebinthus B roots lost an average of $38 \%$ more solutes than $P$. terebinthus A, with the greater difference at low salinity. With 175:12.5
Table 1. Leakage of UV-absorbing solutes $\left(\mathrm{I}_{4}\right)$ from root tips of $P$. terebinthus seedling genotypes exposed to two $\mathrm{Na}: \mathrm{Ca}$ ratios (trial 2).

\begin{tabular}{|c|c|c|}
\hline \multirow[b]{3}{*}{ Genotype $^{y}$} & \multicolumn{2}{|c|}{$I_{t}^{2}$} \\
\hline & \multicolumn{2}{|c|}{$\mathrm{Na}: \mathrm{Ca}$ concn $(\mathrm{mM})$} \\
\hline & $175: 12.5$ & $250: 12.5$ \\
\hline $\begin{array}{l}P . \text { terebinthus A } \\
P . \text { terebinthus B }\end{array}$ & $\begin{array}{l}14.1 \mathrm{~b} \\
46.1 \mathrm{a}\end{array}$ & $\begin{array}{l}82.4 \mathrm{a} \\
87.1 \mathrm{a}\end{array}$ \\
\hline \multicolumn{3}{|c|}{ 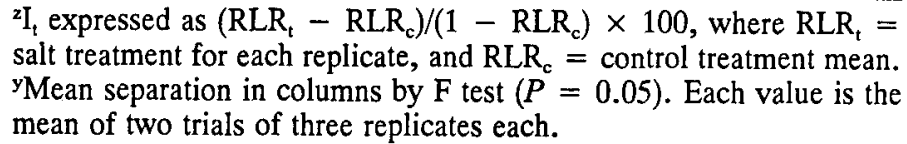 } \\
\hline
\end{tabular}

Table 2. Leakage of UV-absorbing solutes $\left(I_{t}\right)$ from root tips of PG II (trial 3) and $P$. atlantica (trial 4) in various isosmotic solutions.

\begin{tabular}{|c|c|c|}
\hline \multirow[b]{3}{*}{ Solution ${ }^{\mathbf{x}}$} & \multicolumn{2}{|c|}{$I_{t}(\%)^{2}$} \\
\hline & \multicolumn{2}{|c|}{ Osmolality $\left(\mathrm{mOsm} \cdot \mathrm{kg}^{-1}\right)^{\mathrm{y}}$} \\
\hline & 359 & 497 \\
\hline & \multicolumn{2}{|c|}{$P G I I$} \\
\hline $\mathrm{Na} / \mathrm{Ca}$ & $14.3 \mathrm{~b}$ & $42.3 \mathrm{~b}$ \\
\hline $\mathrm{CaCl}_{2}$ & $15.2 \mathrm{~b}$ & $52.1 \mathrm{ab}$ \\
\hline Mannitol & $26.8 \mathrm{~b}$ & $37.0 \mathrm{~b}$ \\
\hline $\mathrm{Na} / 0 \mathrm{Ca}$ & $45.9 \mathrm{a}$ & $64.4 \mathrm{a}$ \\
\hline & \multicolumn{2}{|c|}{ P. atlantica } \\
\hline $\mathrm{Na} / \mathrm{Ca}$ & $23.3 \mathrm{~b}$ & $77.6 \mathrm{a}$ \\
\hline $\mathrm{CaCl}_{2}$ & $9.8 \mathrm{~b}$ & $75.3 \mathrm{a}$ \\
\hline Mannitol & $17.4 \mathrm{~b}$ & $50.8 \mathrm{~b}$ \\
\hline $\mathrm{Na} / 0 \mathrm{Ca}$ & $68.8 \mathrm{a}$ & $90.0 \mathrm{a}$ \\
\hline
\end{tabular}

${ }^{2} \mathrm{I}_{\mathrm{t}}$ calculated as in Table 1.

yLow and high osmolality correspond to $\mathrm{Na}: \mathrm{Ca}$ mixtures of $175: 12.5$ and $250: 12.5 \mathrm{mM}$, respectively.

'Mean separation within columns and species by Duncan's multiple range test $(P=0.05)$. Each value is the mean of three observations.

solution, there was high variability in leakage response of $P$. terebinthus A ( $\mathrm{I}_{\mathrm{t}}$ averages of $20.3 \%$ and $7.9 \%$, compared with $36.0 \%$ and $56.1 \%$ for $P$. terebinthus $\mathrm{B}$ in duplicate trials).

Isosmotic solutions and $\mathrm{Na}$ : Ca ratio. High osmolality significantly increased $\mathrm{I}_{\mathrm{t}}$ only of $P$. atlantica (Table 2; main effects not shown). Substantially higher leakage occurred in $\mathrm{Na} / 0 \mathrm{Ca}$ in both species, with an average $\mathrm{I}_{\mathrm{t}}$ of $76 \%$ (trial 3) to $87 \%$ (trial 4) greater than the means of the other solutions. There was little indication that the simulated $\mathrm{Na} / \mathrm{Ca}$ solutions increased damage over solutions without $\mathrm{Na}$, except when compared with high mannitol in trial 4.

$P$. atlantica responses in trials 1 and 4 were combined to show the influence of increasing salinity and $\mathrm{Na}$ : Ca ratio (Fig. 3). The $\mathrm{Na} / 0 \mathrm{Ca}$ treatments, 194.3 and $269.3 \mathrm{~mm} \mathrm{NaCl}$, were isosmotic to $14: 1$ and 20:1 solutions, respectively, whereas 10:1 solutions had $5 \%$ to $7 \%$ higher osmolality. All $\mathrm{I}_{t}$ values are grouped within the 175 and $250 \mathrm{~mm}$ concentrations for simplicity.

\section{Discussion}

Salinity damaged root tips of $P$. atlantica, $P$. terebinthus, and PG II at $175 \mathrm{~mm} \mathrm{NaCl}$ with 12.5 to $17.5 \mathrm{~mm} \mathrm{Ca}$ (average $\mathrm{EC}$ of $18.1 \mathrm{dS} \cdot \mathrm{m}^{-1}$ in trial 1$)$. This is similar to the soil solution salinity $\left(17.9 \mathrm{dS} \cdot \mathrm{m}^{-1}\right)$ and $\mathrm{Na}: \mathrm{Ca}$ ratio $(174: 13.5)$ that decreased root growth an average of $\approx 60 \%$ (Picchioni et al., 1990). We did not test leakage between 125 and $175 \mathrm{~mm} \mathrm{Na}$. Additional study within this salinity range would determine how 


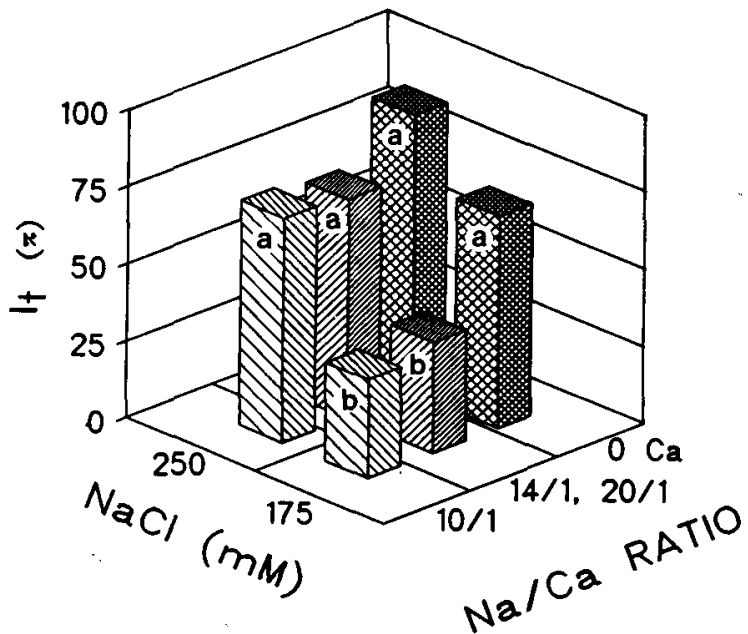

Fig. 3. Solute leakage (I) from root tips of P. atlantica as influenced by $\mathrm{Na}: \mathrm{Ca}$ ratio and $\mathrm{NaCl}$ concentration ( $\mathrm{I}_{t}$ calculated as in Table 1). Center columns with $\mathrm{Na}$ : Ca ratios of $14: 1$ (175:12.5) and 20:1 (250:12.5) represent combined averages of trials 1 and $4(n=3$ for each trial). End columns are the averages of three observations in trial $1(10: 1)$ and trial $4(0 \mathrm{Ca})$. Mean separation within concentrations (main plots) by Duncan's multiple range test, $P=0.05$.

precisely the long-term responses could be simulated by leakage trials.

Laboratory results were best correlated with 2-year, average soil salinity data at the mean soil water content. There was no correlation with salinity of irrigation waters, soil saturation extracts, or the attendant salinity at maximum soil water depletion. For example, the 121:12.5 soil solution level $\left(13.8 \mathrm{dS} \cdot \mathrm{m}^{-1}\right)$, on average, did not significantly affect root growth, although that salinity periodically exeeded $20 \mathrm{dS} \cdot \mathrm{m}^{-1}$ and $175 \mathrm{~mm} \mathrm{Na}$ before irrigation cycles (250:12.5 approximated the 174:13.5 soil solution with lowest soil moisture status).

The minimal $\mathrm{Ca}$ requirement for $175 \mathrm{~mm} \mathrm{NaCl}$ was not established in this study, because a primary objective was to approximate the soil salinity characteristics. Data in Table 2 (low osmolality) suggest that $\mathrm{Ca}$ in lysimeter soil solutions was present in sufficient quantity to alleviate specific $\mathrm{Na}$ effects. However, the possibility that mechanisms of saline injury differed between the studies limits this assurance. Despite the lack of $\mathrm{I}_{t}$ dependence on $\mathrm{Na}$ : Ca ratios between 10:1 and 14:1, there clearly exists a ratio $>14: 1$ at $175 \mathrm{mM} \mathrm{NaCl}$ that would increase membrane permeability. Calcium deficit also increases leakage of solutes from other root tissues, particularly that resulting from exposure to monovalent salts (Poovaiah and Leopold, 1976; Rauser and Hanson, 1966).

Saline injury in leaves has been suggested to result, in part, from limitations in ion absorption, leading to protoplasm desiccation (Munns and Passioura, 1984; Oertli, 1968). This hypothesis could include a range of osmotica affecting excised roots in this study, especially at $497 \mathrm{mOsm} \cdot \mathrm{kg}^{-1}$. With low osmolality, the absence of $\mathrm{Ca}$ intensified cellular damage, but this effect was less significant with the higher concentration. The effects of the Na-only solution contributed in a major way to the presence of a significant interaction in trial 4 (osmolality $\times$ solute type). This factor, along with less Idiversity for PG II, indicate that there was reduced specificity of the $\mathrm{Na} / 0 \mathrm{Ca}$ solution with higher osmolality. In addition, intracellular concentrations of $\mathrm{Na}$ and $\mathrm{Cl}$ in root tips of a related species, $P$. vera $\mathrm{L}$., averaged $<18 \%$ of the intercellular and external solution concentrations (175: 12.5) after standard incubation (Pic- chioni, 1989), indicating a condition of unfavorable water relations.

Cramer and Spurr (1986) observed that Ca increases selective ion transport in the presence of high external $\mathrm{Na}$ in lettuce ( $\mathrm{Lac}$ tuca sativa L.). Other studies have shown that root systems of $P$. atlantica and $P$. terebinthus retain large quantities of $\mathrm{Na}$ in high $\mathrm{Na}$ conditions, thus limiting $\mathrm{Na}$ transport to leaves (Figueroa, 1989; Walker et al., 1987). The capacity of $\mathrm{Na}$ exclusion, however, may be limited by high sodicity. Leaf Na concentrations of trial 1 rootstock increased by $\approx 10$-fold when exposed to the 174:13.5 soil solution, with negligible increases occurring at 121:12.5 (Picchioni et al., 1990), corresponding to leakage estimates in this study. Similar observations with bean (Phaseolus vulgaris L.) showed that within $6 \mathrm{~h}, 50 \mathrm{~mm} \mathrm{NaCl}$ increased $\mathrm{K}$ loss from root tips in vitro (Nassery, 1975), and also caused reduced growth and a large increase $(\approx 9-$ fold) in shoot $\mathrm{Na}$ concentration after 23 days of seedling culture (Lessani and Marschner, 1978). These data suggest that, in Na-excluding species, rising leaf $\mathrm{Na}$ concentrations are the result of marked changes in roots exposed to high $\mathrm{Na}$.

The possibility that excised roots of $P$. terebinthus $\mathrm{B}$ are less tolerant to saline incubation than those of $P$. terebinthus $\mathrm{A}$ is of interest. In the 174:13.5 lysimeter solution, P. terebinthus B contained $\approx 140 \%$ more $\mathrm{Na}$ in leaf tissue and $\approx 33 \%$ to $66 \%$ less $\mathrm{Na}$ in whole roots and basal stems, respectively, than four other pistachio rootstock (Picchioni et al., 1990). This is of practical importance for rootstock selection, but leaves unanswered the question of whether the $\mathrm{Na}$ storage capacity was merely limited (Jacoby, 1964), or whether the storage was directly involved in root injury (Bernstein, 1975). For example, Levitt (1980) stated that saline tolerance may be controlled by the composition of cell membranes (lipid and bound protein constituents).

We experienced leakage variability between trials with all species and selections, which was highest for $P$. terebinthus A $(\approx 60 \%$ in trial 2$)$. A possible explanation is the time elapsed during the duplicate trials ( $\approx 30$ days), even though we could not detect macroscopic root differences between sampling periods. Redmann et al. (1986) found leakage of UV-absorbing solutes from 24-h salt-treated leaves of aspen (Populus tremuloides Michx.) declined with leaf age during a 30-day sampling period, but there was no consistent relationship between root salt tolerance and culture time in this study. Differences in root growth rates, as well as background leakage (Flint et al., 1967), may also have caused between-trial variation.

Coefficients of variation averaged $35 \%$ for solutions causing root injury. This indicates that precision may be improved by increasing the number of observations or the number of roots per incubation, even though these were limitations in our study. Other studies have used shorter treatment durations (2 to $6 \mathrm{~h}$ ) and greater amounts of root tissue (Nassery, 1975; Rauser and Hanson, 1966). About 10 to $25 \mathrm{mg}$ fresh weight of tissue was available for each 24-h incubation. This raised the possibility that irreversible damage by $\mathrm{CaCl}_{2}$ and mannitol eliminated specific effects of $\mathrm{Na} / \mathrm{Ca}$ simulations. However, the effects of all three osmotica were similar even with a $75 \%$ reduction in exposure time $(6 \mathrm{~h})$, except $\mathrm{A}_{260}$ measurements were $\approx 30 \%$ lower before freezing (data not shown). Thus, much of the cell injury occurred within $6 \mathrm{~h}$, but longer duration increased test sensitivity without altering the results.

The preparation of seedling rootstock material need not be as prolonged as in the above conditions. For example, root tips from 2-month-old $P$. atlantica responded much like those from 
seedlings aged 3 years in the leakage trials. We also found that young lateral roots from pecan seedlings [Carya illinoen.sis (Wangenh.) C. Koch], which are less saline-resistant than Pistacia spp. in lysimeter conditions (Miyamoto et al., 1985), are also less tolerant to saline incubation (e.g., leakage at ,100 mM $\mathrm{NaCl}$ ). Thus, this approach also may have potential for other tree crops.

The correlation between lysimeter data and that obtained in the present study indicates that solute leakage tests with roots might provide a simple and rapid means of characterizing salinity responses of rootstock. Such aspects could include saline resistance and differential avoidance of adverse ion relations.

\section{Literature Cited}

Bernstein, L. 1975. Effects of salinity and sodicity on plant growth. Annu. Rev. Phytopath. 13:295-312.

Cramer, G.R. and A.R. Spurr. 1986. Salt responses of lettuce to salinity. II. Effect of calcium on growth and mineral status. J. Plant. Nutr. 9:131-142.

Figueroa-V., U. 1989. Comportamiento de cultivates y portainjertos de pistache (Pistacia spp.) en condiciones de salinidad. MS Thesis, Colegio de Postgraduados, Institución de Enseñanza e Investigación en Ciencias Agricolas, Centro de Fruticultura, Chapingo, Mexico.

Flint, H. L., B.R. Boyce, and D.J. Beattie. 1967. Index of injury-a useful expression of freezing injury to plant tissues as determined by the electrolytic method. Can. J. Plant Sci. 48:229-230.

Goldhammer, D., R. Phene, J. MacDonald, S. Fiero, and R. Beede. 1989. Influence of irrigation method on the distribution of roots and water in a high verticillium pistachio orchard. Calif. Pistachio Ind. Annu. Rpt. Crop Year 1987-1988. Calif. Pistachio Commission, Calif. Pistachio Assn., Fresno, p. 97-98.

Greenway, H. 1970. Effects of slowly permeating osmotica on metabolism of vacuolated and nonvacuolated tissues. Plant Physiol. 46:254258.

Hoagland, D.R. and D.I. Arnon. 1950. The water-culture method for growing plants without soil. Calif. Agr. Expt. Sta. Circ. 347.

Jacoby, B. 1964. Function of bean roots and stems in sodium retention. Plant Physiol. 39:445-449.

Leopold, A.C. and R.P. Willing. 1984. Evidence for toxicity effects of salt on membranes, p. 67-76. In: R.C. Staples and G.H. Toenniessen (eds.). Salinity tolerance in plants. Wiley, New York.

Lessani, H. and H. Marschner. 1978. Relation between salt tolerance and long-distance transport of sodium and chloride in various crop species. Austral. J. Plant Physiol. 5:27-37.
Levitt, J. 1980. Salt and ion stresses. Responses of plants to environmental stresses. 2nd ed. vol. 2. Academic, New York. p. 365-488.

Little, T.M. and F.J. Hills. 1978. Agricultural experimentation. Wiley, New York.

Maas, E.V. and R.H. Nieman. 1978. Physiology of plant tolerance to salinity, p. 277-299. In: G.A. Jung (cd.). Crop tolerance to suboptimal land conditions. Amer. Sot. Agron. Spec. Pub. 32.

Milbocker, D.C. 1988. Salt tolerance of azalea cultivars. J. Amer. Soc. Hort. Sci. 113:79-84.

Miyamoto, S., G.R. Gobran, and K. Piela. 1985. Salt effects on seedling growth and ion uptake of three pecan rootstock cultivars. Agron. J. $77: 383-388$.

Munns, R. and J.B. Passioura. 1984. Effect of prolonged exposure to $\mathrm{NaCl}$ on the osmotic pressure of leaf xylem sap from intact, transpiring barley plants. Austral. J. Plant Physiol. 11:497-507.

Nassery, H. 1975. The effect of salt and osmotic stress on the retention of potassium by excised barley and bean roots. New Phytol. 75:6367.

Nassery, H. 1979. Salt-induced loss of potassium from plant roots. New Phytol. 83:23-27.

Oertli, J.J. 1968. Extracellular salt accumulation, a possible mechanism of salt injury in plants. Agrochimica 12:461-469.

Picchioni, G.A. 1989. Growth, ion uptake, and some metabolic processes of Pistacia spp. affected by salinity and boron. PhD Diss., Texas A\&M Univ., College Station. (Diss. Abstr. 90-15,564.)

Picchioni, G. A., S. Miyamoto, and J.B. Storey. 1990. Salt effects on growth and ion uptake of pistachio rootstock seedlings. J. Amer. Soc. Hort. Sci. 115:647-653.

Poovaiah, B.W. and A.C. Leopold. 1976. Effects of inorganic salts on tissue permeability. Plant Physiol. 58:182-185.

Rauser, W.E. and J.B. Hanson. 1966. The metabolic status of ribonucleic acid in soybean roots exposed to saline media. Can. J. Bet. 44:759-776.

Redmann, R. E., J. Haraldson, and L.V. Gusta. 1986. Leakage of UVabsorbing substances as a measure of salt injury in leaf tissue of woody species. Physiol. Plantarum 67:87-91.

Richards, D. 1983. The grape root system. Hort. Rev. 5:127-168.

Rem, R.C. 1987. Roots, p. 5-28. In: R.C. Rom and R.F. Carlson (eds.). Rootstock for fruit crops. Wiley, New York.

Snedecor, G.W. and W.G. Cochran. 1989. Statistical methods. 8th ed. Iowa State Univ. Press, Ames.

Walker, R. R., E. Törökfalvy, and M.H. Behboudian. 1987. Uptake and distribution of chloride, sodium and potassium ions and growth of salt-treated pistachio plants. Austral. J. Agr. Res. 38:383-394.

Willing, R.P. and A.C. Leopold. 1983. Cellular expansion at low temperature as a cause of membrane lesions. Plant Physiol. 71:118121. 